
$\angle$ Research Square
Preprints are preliminary reports that have not undergone peer review.
They should not be considered conclusive, used to inform clinical practice,
or referenced by the media as validated information.

\title{
The density and peaks of seasonal activity of Dermacentor reticulatus ticks in eastern Poland
}

Zbigniew Zając ( $\nabla$ zbigniew.zajac@umlub.pl )

Medical University of Lublin

Aneta Woźniak

Medical University of Lublin

Joanna Kulisz

Medical University of Lublin

\section{Research}

Keywords: ticks density, Dermacentor reticulatus, ticks distribution, ticks activity

Posted Date: December 18th, 2019

DOI: https://doi.org/10.21203/rs.2.19169/v1

License: () (1) This work is licensed under a Creative Commons Attribution 4.0 International License. Read Full License 


\section{Abstract}

Background: Next to Ixodes ricinus, Dermacentor reticulatus ticks are the most important reservoir and vector of infectious diseases in Europe. In recent years, progressing expansion of D. reticulatus ticks into new territories and an increase in their population size in areas of their previous occurrence have been observed.

Methods: The studies on tick population density were conducted in Lublin Province, eastern Poland. The investigated area was divided into 101 equal squares (plots). Additionally, studies on seasonal activity in the preferred habitat of the ornate cow ticks were conducted from 2014 to 2019 in the Polesie National Park.

Results: Throughout the study on the tick population density, 19559 adult D. reticulatus specimens were collected. An average density of the ornate cow ticks in Lublin Province was 96.8 specimens $/ 100 \mathrm{~m} 2$. A significant impact on the tick population density is exerted by meadow areas (Rs=0.281, $p=0.0044)$, while weather conditions have no effect $(H=6.08, p=0.1931)$. The local population of $D$. reticulatus ticks in the eastern and middle regions of Lublin Province exhibits predominance of spring activity peaks, while autumnal seasonal activity peaks prevail in the rest of the region. Multiannual monitoring of the seasonal activity of D. reticulatus in the Polesie National Park shows the prevalence of autumnal activity peaks in 2014-2019 and spring activity peaks in 2019.

Conclusions: The area of Lublin Province is characterized by high density of the ornate cow ticks. Local populations of D. reticulatus show two peaks of seasonal activity. Dynamics of seasonal activity of D. reticulatus is influenced by availability of their hosts. The highest risk of ornate cow tick attacks on animals and humans occurs during spring in the eastern part and in autumn in the western part of Lublin Province.

\section{Background}

Dermacentor reticulatus belongs to the most widely spread tick species throughout Europe. According to many authors, two geographically separated populations of ornate cow ticks are distinguished - the "western European" and "eastern European" population. This phenomenon is not found in other widely distributed ticks species in Europe i.e. Ixodes ricinus or D. marginatus [1, 2].

In Western Europe, the compact area of ornate cow tick distribution includes the southern part of the British Islands, France, Switzerland, Benelux, and Germany [2-5]. Specimens of this species are most commonly collected from plants as well as wild, farm, and domestic animals in Central Europe. The lowlands of the Czech Republic, western Slovakia, Hungary, Slovenia, and Austria should be considered as endemic areas for this species. D. reticulatus from the regions mentioned above are included into the western European population of this species [6-10].

The compact range of the eastern European D. reticulatus population covers eastern Poland, Ukraine, Belarus, Lithuania, Latvia, Estonia, and the north-west of the European part of Russia. Numerous sites of ornate cow tick occurrence have been reported from the Caucasus and Asia to Omsk and Novosibirsk [4, 1114].

Until the beginning of the $21^{\text {st }}$ century, it was thought that the compact area of $D$. reticulatus distribution in Poland is limited to the territory located to the east of the Vistula River and in north-eastern part of the country, while western regions were considered free from this species. Simultaneously, it was accepted that the border between the eastern and western population of $D$. reticulatus ran through Poland $[12,15,16]$. Studies on tick ecology and distribution, which have been intensified in recent years by Polish scientists, confirmed the occurrence of the species also in the northern, western and south-western territory of Poland [17-24]. As suggested by some authors, this phenomenon should be referred to as expansion of ornate cow ticks to new areas [21, 25].

Similar changes in the dynamics and distribution of local $D$. reticulatus populations were observed in other European countries, e.g. in Germany where before the 70 s of the $20^{\text {th }}$ century its distribution was limited to western Lands, and the described population was not numerous [26]. In the next years, expansion to eastern Lands bordering Poland was observed [7]. Many new D. reticulatus occurrence sites were reported in the Czech Republic. In Slovakia, new sites of distribution of ornate cow ticks representing both eastern European and western European populations were reported [27, 28]. In recent years, expansion of $D$. reticulatus ticks was observed in Hungary, where only two sites of occurrence were documented before the 70s of the past century [8]. A similar process of expansion was also observed in Romania [10, 29].

Clustered populations of D. reticulatus were confirmed in the south of the continent, i.e. in the Balkan [30-33] and Iberian peninsulas [34]. The spread of ornate cow ticks to Scandinavia [35] and northern Italy, which were regarded as tick-free previously has been observed during the last years [36].

D. reticulatus populations in Europe are separated by a geographical border that has been disappearing lately due to the expansion of the tick species. Since genetic studies on specimens of both populations have shown no differences between their genomes, there is still an unanswered question about gaps in the D. reticulatus distribution in Europe [37].

The aim of our research was to conduct simultaneous large-scale studies of the occurrence and density of $D$. reticulatus population in eastern Poland. The investigations were also focused on the seasonal activity rhythms of this species in Lublin Province with their determinants, periods of a high risk of infestation of hosts, and risks of tick-borne pathogen transmission.

\section{Methods}

Density and seasonal activity peak rhythms of the $D$. reticulatus population

Determination of the experimental fields 
The studies on the density of D. reticulatus ticks in eastern Poland were conducted in Lublin Province (Fig. 1). A grid of 101 squares with 15.8-km long sides (plots) was applied to a physical map of the investigated area (Fig. 2). An average area of each square was $250 \mathrm{~km}^{2}$, which represents $1 \%$ of Lublin Province. Plots $1,2,19,27,35,44,53,63,81,89,96,97,100$, and 101 were the exceptions, as they had smaller areas due to the course of administrative boundaries of the Province. At the same time, they constituted more than $60 \%$ of the area marked by the described grid.

The next stage included the use of satellite pictures available in Google Maps [38] to determine potential sites of species collection. Meadows undergoing ecological succession located on the edge of forests or in its vicinity and with access to watercourses were regarded as preferred tick habitats (Fig. 3).

Tick collection

The potential areas of tick collection were surveyed previously. Field studies were conducted during seasonal peaks (spring and autumn) of tick activity in Lublin Province. Determination of the activity peaks was based on the literature data [39-41] and on simultaneous monitoring of the $D$. reticulatus activity in different parts of Lublin Province. Ticks were collected during the spring peak between 18.03.2019 and 31.03.2019 and from 12.10.2019 to 24.10.2019 in autumn (square number 93 was excluded due to ongoing construction works).

Ticks were collected with the standard flagging method. Plants were swept with 1- $\mathrm{m}^{2}$ flannel fabric on a 100- $\mathrm{m}^{2}$ experimental field. During tick collection, weather conditions, i.e. air temperature and relative humidity, were measured with the use of Data Logger R6030.

During the laboratory study, the collected specimens were identified to the species level, developmental stage, and sex with the use of a stereoscopic microscope Zeiss STEMI DV4 and identification guide compiled by Estrada-Peña et al. [42].

Analysis of the land structure of the study area

With use of tools for measuring the distances and surface area in Google Maps [38] and satellite pictures, the percentage structure of the area in each square was calculated. The surface of the cultivated land, forests, and meadows was analyzed. The term "other" means buildings, water resource types, and areas that could not be classified clearly.

Analysis of the weather conditions

The historical data on the weather conditions from 2015-2019 in different regions of Lublin Province were retrieved from the Internet service tutiempo.net [43]. Data of the Terespol weather station were accepted as representative for the north-eastern region of Lublin Province, while the stations in Włodawa, Zamość, and Kozienice provided relevant data on the eastern, southern, and western regions, respectively (Fig. 4).

Multi-annual monitoring of the $D$. reticulatus seasonal activity

The studies on the seasonal activity of $D$. reticulatus ticks were conducted from 2014 to 2019 in the Polesie National Park located in the middle-eastern part of Lublin Province (square number 41). They were a continuation of studies started in 2012 [41].

The methods of collection and identification of specimens to the species level and developmental forms were the same as described above. Ticks were collected in equal periods from March to November. Throughout the study period, ticks were collected in the same habitat. The study was accepted by the Minister of Environment by virtue of permission DOP-WPN.286.312.2019.MD and DLP-III-4102/16/1278/15/MD.

Statistical analysis

Statistical analysis of differences between the number of active $D$. reticulatus females and males within the experimental fields was performed with the use of the Wilcoxon signed-rank test. A multiple regression model was used to assess the impact of the land structure on the tick population density. The significance of the impact of temperatures and air humidity on the tick population density was evaluated with the use of Spearman's Rank correlation coefficient. The weather parameters in the different regions of the province were analyzed with the Kruskal-Wallis test.

The Kruskal-Wallis test was used for statistical analysis of the number of active $D$. reticulatus females and males in the springs and autumns throughout the study period. A multiple regression model was used to assess the significance of differences in the seasonal activity of ticks in 2014-2019. The impact of air temperature and relative humidity on active ticks at the time of collection was checked by Spearman's Rank correlation coefficient.

In all statistical tests, the significance level was $p<0.05$. The statistical analysis was conducted with Statistica 10PL software.

Study area

Lublin Province has an area of $25,122 \mathrm{~km}^{2}$, which accounts for $8.02 \%$ of the territory of Poland. The border between three megaregions differing in the geomorphological structure, water features, and climate, i.e East European Plain, Extra-Alpine Central Europe, and Carpathian Region, runs across the province area [44].

The eastern and north-eastern parts of Lublin Province are located in western Polesie and Volhynian Polesie (Fig. 4). These regions are located in the basin of the Bug - one of the longest rivers in Poland. The subsoil consists mainly of marls and chalk, hence the presence of many lakes and bogs. The regions are characterized by high woodiness and very low average air temperature values. At the same time, this area is exposed to the lowest anthropopressure in Poland [44]. 
The western part of the study area belongs to the South Podlasie Plain. This region is typically agricultural with high ratio of wastelands. The climate is more temperate, especially in the western regions. The central area of Lublin Province is part of Lublin Upland. Fawn and podzol soils form the subsoil, while brown soils are the substrate in the river valleys. Landform is pleated. This part of the province is intensively used for agriculture and has been almost deforested [44].

The southern outskirts of the study area are part of Roztocze. This is the highest area of the region, with climate close to continental and marls, opoka rocks, and limestone in its subsoil. Rivers in this area have a mountain character [44].

\section{Results}

The density and peaks of D. reticulatus population activity

In total, 19559 adult $D$. reticulatus specimens were collected throughout the study period, including 11598 females and 7961 males (Table 1 ). An average density of the ornate cow tick population in Lublin Province was 96.8 specimens $/ 100 \mathrm{~m}^{2}$ with statistically significant dominance of females $(Z=8.19, p<0.001)$. The ticks population density was higher in autumn than in spring (Table 2). The greatest population density was observed in the northern part of the study area (plots 1-18). It varied from 86 specimens to 311 specimens $/ 100 \mathrm{~m}^{2}$ throughout the study period. The lowest density of the $D$. reticulatus population was noted in the central part of the province. However, the lowest number of ticks were collected in square 67 , where the population density was 22 specimens/100 $\mathrm{m}^{2}$ (Table 1, Fig. 5).

The predominance of active $D$. reticulatus ticks in autumn was observed in the northern, southern, and western part of Lublin Province, while in the middle and eastern parts of region, the highest number of ticks were collected in spring (Table 1, Fig. 2).

In the regression model of the density of the ornate cow ticks, none of the land structure variables (arable lands, forests, meadows) has statistical significance $\left(F_{(3.97)}=1.05, p=0.3728\right)$. However, Spearman's Rank correlation coefficient indicates that the density of active $D$. reticulatus females and males rises with the increase in the meadow area (Rs=0.281, $p=0.0044)$.

The weather conditions observed in the particular parts of the region in 2019 were not significantly different (average air temperature $\mathrm{H}=0.18$, $\mathrm{p}=0.9962$; relative air humidity $\mathrm{H}=2.00, \mathrm{p}=0.7354$; total precipitation $\mathrm{H}=0.82, \mathrm{p}=0.9361$; number of days with snow cover $\mathrm{H}=0.06$, $\mathrm{p}=0.9995$; number of days with fog $\mathrm{H}=6.08, \mathrm{p}=0.1931$ ). These parameters had no statistically significant impact on differences in the tick density between the particular study areas (average air temperature $p=0.2848$; relative air humidity $p=0.1881$; total precipitation $p=0.3910$; number of days with snow $\operatorname{cover} p=0.3910$ ).

The statistical analysis of the weather parameters in 2015-2019 did not show statistically significant differences between the parts of Lublin Province $(H=0.91, p=0.9901)$.

Multiannual monitoring of the seasonal activity of $D$. reticulatus ticks

In the Polesie National Park $\left(51^{\circ} 22^{\prime} \mathrm{N}, 30^{\circ} 30^{\prime} \mathrm{E}\right)$, a tendency towards an increase in the number of active $D$. reticulatus ticks was observed in 2014-2018. The substantial dominance of the average number of active ticks in autumn over spring was revealed. Simultaneously, more females were collected. In 2019 , more active ticks were collected in spring than in autumn (331 to 93 specimens, respectively) (Table 3).

In each year from 2014 to 2018, a statistically significant difference between the number of active $D$. reticulatus ticks in spring and autumn was confirmed $(H=6.98, p=0.047)$. However, there was no statistically significant difference in the number of active ticks between the study years $(H=3.94, p=2678)$. Moreover, a statistically significant difference in the number of active ticks in $2014-2018$ was revealed $(\mathrm{H}=4.87, \mathrm{p}<0.014)$. The seasonal activity of $D$. reticulatus ticks is significantly influenced by the air temperature prevailing during tick collection $(H=12.887, p=0.002)$.

\section{Discussion}

The dynamics and size of the D. reticulatus population, as in the case of other hard ticks, depend on many biotic and abiotic factors. The most important include the presence of potential hosts, ecological type of occupied habitats, climatic factors, photoperiod, excreted semiochemical substances and hormones controlling the rhythms of seasonal activity, diapause periods, and biology of tick reproduction and development $[13,39,45,46]$.

In eastern Poland, the greatest impact on the seasonal and diurnal rhythms of D. reticulatus activity is exerted by air temperature prevailing during tick collection [40,41]. Together with air humidity, it can affect the questing behavior [47] and locomotor abilities of this species [48]. This dependence is confirmed by the results of our long-term studies on seasonal tick activity in the Polesie National Park $(H=12.887, p=0.002)$.

D. reticulatus ticks have a wide range of ecological tolerance to environmental factors. Adult specimens can be active during winter months [49, 50$]$ even at negative ambient temperature values, while in laboratory conditions they are able to survive up to 150 days at $-10^{\circ} \mathrm{C}$ [51]. As demonstrated by Hubalek et al. [52], the limit temperature value allowing ticks for host seeking up to $-0.1^{\circ} \mathrm{C}$.

The area of Lublin Province has the highest density ( 96.8 specimens $/ 100 \mathrm{~m}^{2}$ ) of tick populations at the peak of their seasonal activity of all areas studied in Poland (Table 1). The number of active adult D. reticulatus specimens recorded in Lublin Province is 13.2 times higher than in Mazovia (central Poland; an average of 7.4 specimens $/ 100 \mathrm{~m}^{2}$ in 2012-2014), 15.6 times higher than in Lubuskie Province (western Poland), and 32.3 time higher than in the West Pomeranian Province (north-western Poland) [21]. 
The density of the D. reticulatus tick population in Lublin Province is high but unevenly distributed (Fig. 5). On average, most ticks were collected in the experimental fields of squares located in the northern and north-eastern part of the region (South Podlasie Lowland, Polesie Lubelskie) (Fig. 4, Table 1). These areas have the largest meadows areas in the entire province. An increase in the meadow area positively correlates and has a statistically significant impact on the number of collected ticks (Rs $=0.281, p=0.0044$ ). It should be noticed that a significant percentage of this area is occupied by wastelands and forest islands (Table 1). The mosaic character of the landscape offers beneficial conditions for D. reticulatus populations. Forests provide availability of host species for adult specimens, while meadows and wastelands are preferred habitats for rodents - hosts of juvenile forms of ticks.

The greatest density of D. reticulatus ticks throughout the whole study period was observed in the experimental field located in plot 69 placed in Lublin Upland (Fig. 4). During single collection in the spring activity peak, 516 specimens of ornate cow ticks were harvested (297 females and 219 males) per 100 m² area (Table 1, Fig. 5, Fig. 6). Attention should be drawn to the lowest density of tick populations in the neighboring sites (located in the same macroregion) ranging from 10 to 100 specimens $/ 100 \mathrm{~m}^{2}$ (Fig. 5). Therefore, the high density of ornate cow ticks is a result of the ecological character of the habitat. The site where the greatest number of ticks was collected is surrounded by an uncut meadow, a watercourse, and a forest. The forest cover is $<8 \%$ in the scale of the whole macroregion and $22 \%$ for the province (Table 1 ). With its fertile soils, the area is intensively used for agriculture.

As indicated by Mierzejewska et al. [52] the spread of D. reticulatus is associated with the loss of forest area. We agree with this opinion but with the provision that deforestation cannot lead to transformation of woodlands into an agricultural area because this would limit the range of ticks distribution and decrease the population size. Large woodland areas have an important impact on tick population density in Lublin Province. The number of ticks collected in squares 73 and 74 (woodland $>61 \%$, meadow area 1.93\%) located within the biggest forest of Lublin Province ("Janów Forest") was significantly lower than an average of the region, i.e. 29 and 23 specimens $/ 100 \mathrm{~m}^{2}$ in spring and 46 and 30 specimens $/ 100 \mathrm{~m}^{2}$ in autumn, respectively (Table 1). The results of our studies show that D. reticulatus populations can endure and steadily grow only in areas with appropriate proportions between forests and meadows/wastelands. However, small isolated populations of D. reticulatus ticks can exist in habitats where these proportions are disturbed.

D. reticulatus ticks mostly exhibit two outstanding peaks of seasonal activity: in spring and autumn. In the French Alps, the European part of Russia, and north-eastern Poland, a higher number of ticks are active during spring $[13,53,54]$. The data published so far indicate that the ornate cow tick population in eastern Poland is characterized by even three-fold higher number of ticks collected in autumn [39, 40, 41, 47]. During our study, we observed predominance of the spring peak in the central and eastern parts of the region (Fig. 2) and the autumn peak in the other parts of the province. The seasonal activity of D. reticulatus during the year and the population density are not influenced by weather conditions, which were not significantly different in the whole study area over the last 5 years $(H=6.08, p=1931)$. Similar dependences were described in studies on colonization of new areas by ornate cow ticks in western Poland [52]. The results of our study demonstrate that changes in the pattern of seasonal activity may occur in the same population that is stable in terms of its seasonal activity rhythms and growth (ongoing long-term investigations). The D. reticulatus population in the Polesie National Park (square 41) monitored for the last 7 years [41] exhibited a significantly higher number of active ticks in autumn in 2012-2018 and dominance of the spring peak of activity over autumn in 2019 with a ratio of 331:93 (Table 3). Because the experimental field is located within a protected area, the anthropogenic impact is limited to a minimum. We believe that the size and dynamics of the $\mathrm{D}$. reticulatus seasonal activity are influenced mostly by the availability of preferred hosts occurring in investigated area, i.e. roe deer Capreolus capreolus, deer Cervus elaphus, elks Alces alces, and wild boars Sus scrofa. Our unpublished observations demonstrate the highest tick infestation in wild boars. These animals occur in the whole province and their population size has been growing during the last years, even up to $178 \%$ (from 6,400 to 17,800 specimens within 5 years). For comparison, the elk population in the same time comprised 2,300 and deer 7,600 individuals [55].

In 2017-2018, a decrease in the size of wild boar populations was observed in Lublin Province due to the confirmed outbreaks of ASF (African swine fever). Before April 2018, 1942 specimens were found dead in eastern Poland because of this viral disease [56]. Furthermore, during this period, the wild boar population was reduced preventively. This led to a significant decrease in the number of animals that are one of a main preferred hosts of D. reticulatus [17, 57]. This situation is reflected in the structure of the size and dynamics of seasonal activity of eastern Poland populations of D. reticulatus and explains the spatial distribution of the activity peaks of this tick species in Lublin Province. Considering the survivability of adult specimens in a habitat over 2 years [13], the predominance of tick activity peaks in spring in areas where the autumn peak was presented previously [41] (Table 3) can be caused by an insufficient amount of hosts for adult ticks. Nevertheless, an impact of other factors on this phenomenon should not be excluded and further observations and research are required.

The high population density of D. reticulatus ticks in Lublin Province is associated with a greater risk of tick attack on animals and sporadically on humans than in other country regions and increases the possibility of transmission of tick-borne pathogens. Diverse pathogens have been confirmed in ornate cow ticks, i.e. Anaplasma phagocytophilum, Rickettsia raoultii, Borrelia burgdorferi s. I., Babesia spp., and TBE virus [58]. The increase in the tick population density in this area can result in a future increase in the incidence of tick-borne diseases [59]. Numerous cases of canine babesiosis and domestic animal borreliosis have been currently reported in Lublin Province [60, 61, 62].

\section{Conclusions}

D. reticulatus ticks occur in the whole area of the Lublin Province. This region is characterized by a high level of activity of ornate cow ticks, which however is unevenly distributed. Local D. reticulatus populations exhibit differences in the peaks of seasonal activity determined mostly by availability of potential hosts.

The highest risk of D. reticulatus attacks on animals and humans occurs in spring in the eastern and central parts of the region but in autumn in the north and western parts of the province.

\section{Declarations}


Ethics approval and consent to participate

The study was accepted by the Minister of Environment by virtue of permission DOP-WPN.286.312.2019.MD and DLP-III-4102/16/1278/15/MD.

Consent for publication

Photos used in Fig. 3 and Fig. 6 were taken by Zbigniew Zając, corresponding author of this manuscript

Availability of data and materials

The climate data analyzed during the current study are available in https://en.tutiempo.net/climate/poland.html

Competing interests

The authors declare that they have no competing interests

Funding

Not applicable

Authors' contributions

ZZ: study design, ticks collection, data analysis, writing manuscript; AW: ticks collection, data analysis, writing manuscript, JK: ticks collection, data analysis, writing manuscript

Acknowledgements

Not applicable

Authors' information (optional)

Not applicable

\section{References}

1. Földvári G, Široký P, Szekeres S, Majoros G, Sprong H. Dermacentor reticulatus: a vector on the rise. Parasit Vectors. 2016; doi:10.1186/s13071-016-1599$x$.

2. Rubel F, Brugger K, Pfeffer M, Chitimia-Dobler L, Didyk YM, Leverenz S, et al. Geographical distribution of Dermacentor marginatus and Dermacentor reticulatus in Europe. Ticks Tick Borne Dis. 2016; doi:10.1016/j.ttbdis.2015.10.015.

3. Bonnet S, De la Fuente J, Nicollet P, Liu X, Madani N, Blanchard B, et al. Prevalence of tick-borne pathogens in adult Dermacentorticks from nine collection sites in France. Vector Borne Zoonotic Dis. 2013; doi:10.1089/vbz.2011.0933.

4. Karbowiak G. The occurrence of the Dermacentor reticulatus tick - its expansion to new areas and possible causes. Ann Parasitol. 2014;60:37-47.

5. Jongejan F, Ringenier M, Putting M, Berger L, Burgers S., Kortekaas R, et al. Novel foci of Dermacentor reticulatus ticks infected with Babesia canis and Babesia caballi in the Netherlands and in Belgium. Parasit Vectors. 2015; doi:10.1186/s13071-015-0841-2.

6. Földvári G, Farkas R. Ixodid tick species attaching to dogs in Hungary. Vet Parasitol. 2005;129(1-2):125-31.

7. Dautel H, Dippel C, Oehme R, Hartelt K, Schettler E. Evidence for an increased geographical distribution of Dermacentor reticulatus in Germany and detection of Rickettsia RpA4. Inn J Med Microbiol. 2006;2 Suppl 40:149-56.

8. Sreter T, Szell Z, Varga I. Spatial distribution of Dermacentor reticulatus and Ixodes ricinus in Hungary: evidence for change? Vet Parasitol. 2005;128:34751.

9. Špitalská E, Štefanidesová K, Kocianová E, Boldiš V. Rickettsia slovaca and Rickettsia raoultii in Dermacentor marginatus and Dermacentor reticulatus ticks from Slovak Republic. Exp App Acarol. 2012; doi:10.1186/s13071-017-2094-8.

10. Chitimia-Dobler L. Spatial distribution of Dermacentor reticulatus in Romania. Vet Parasitol. 2015; doi:10.1016/j.vetpar.2015.09.018.

11. Olsuf'ev NG. On ecology of the meadow tick Dermacentor pictus, origin of its foci, and ways of eradicating it in the middle of the European part of RSFSR. Problems Reg Gen Exp Parasitol Med Zool Moscow. 1953;8:49-98. (In Russian).

12. Szymański S. Distribution of the tick Dermacentor reticulatus (Fabricus, 1794)(Ixodidae) in Poland. Acta Parasitol. 1986;31(13):143-154.

13. Razumova I. The activity of Dermacentor reticulatus (Ixodidae) ticks in nature. Med Parazitol (Mosk). 1998;4:8-14. (In Russian).

14. Paulauskas A, Radzijevskaja J, Turčinavičienė J, Ambrasienė D, Galdikaitė E. Data on some Ixodid tick species (Acari, Ixodidae) in the Baltic countries. New Rare Lith Insects Species. 2010;22:43-51.

15. Lachmajer J. The state of research on Arthropoda parasites in Poland. Ann Parasitol. 1963;9(04). (In Polish).

16. Siuda K. Ticks (Acari: Ixodida) of Poland. Part II Taxonomy and Distribution. Polish Parasitological Society; 1993.

17. Fryderyk S. A new interesting finding of Dermacentor reticulatus (Fabr.) (Acari: Ixodida: Ixodidae) on the wild boar (Sus scrofa). Ann Parasitol. 1998;44:737-39. (In Polish). 
18. Kadulski S, Izdebska JN. New data on distribution of Dermacentor reticulatus (Fabr.) (Acari, Ixodidae) in Poland. In: Buczek A, Błaszak C, editors. Arthropods and their invasions. Lublin: Akapit, 2009. p. 53-58.

19. Nowak M. Discovery of Dermacentor reticulatus (Acari: Amblyommidae) populations in the Lubuskie Province (Western Poland). Exp App Acarol. 2011;54(2):191-197.

20. Kiewra D, Czułowska A. Evidence for an increased distribution range of Dermacentor reticulatus in south-west Poland. Exp App Acarol. 2013; doi:10.1007/s10493-012-9612-3.

21. Mierzejewska EJ, Estrada-Peña A, Alsarraf M, Kowalec M, Bajer A. Mapping of Dermacentor reticulatus expansion in Poland in 2012-2014. Ticks Tick Borne Dis. 2016; doi:10.1016/j.ttbdis.2015.09.003

22. Opalińska P, Wierzbicka A, Asman M. The PCR and nested PCR detection of Borrelia burgdorferi sensu lato, Anaplasma phagocytophilum and Babesia microti in Dermacentor reticulatus collected in a new location in Poland (Trzciel, Western Poland). Acta Parasitol. 2016; doi:10.1515/ap-2016-0117.

23. Król N, Kiewra D, Lonc E, Janaczyk B, Chodorowska-Skubiszewska A, Dzięcioł M, et al. Dermacentor reticulatus (Fabricius, 1794) and Babesia canis (Piana et Galli-Valerio, 1895) as the parasites of companion animals (dogs and cats) in the Wroclaw area, south-western Poland. Ann Parasitol. 2016; doi: 10.17420/ap6202.44.

24. Kubiak K, Sielaw, H, Dziekońska-Rynko J, Kubiak D, Rydzewska M, Dzika E. Dermacentor reticulatusticks (Acari: Ixodidae) distribution in northeastern Poland: an endemic area of tick-borne diseases. Exp App Acarol. doi: 10.1007/s10493-018-0274-7.

25. Mierzejewska EJ, Pawełczyk A, Radkowski M, Welc-Falęciak R, Bajer A. Pathogens vectored by the tick, Dermacentor reticulatus, in endemic regions and zones of expansion in Poland. Parasit Vectors. 2015; doi:10.1186/s13071-015-1099-4.

26. Immler RM. Studies on the biology and ecology of Dermacentor reticulatus tick (Fabricius, 1794) (Ixodidae) in an endemic area. Mitt Schweiz Entomol Ges 1973;46:2-70. (in German).

27. Daniel M, Černy V, Szymański S. A comparison of factors influencing the distribution of Dermacentor reticulatus (Ixodidae) in Czechoslovakia and Poland. Ann Parasitol. 1986;32: 355-61.

28. Labuda M, Lysy J, Krippel E. Ixodes ricinus, Haemaphysalis concinna and Dermacentor reticulatus (Acarina, Ixodidae) ticks collected from small mammals in West Slovakia. Biológia. 1989;44:897-09. (In Slovak).

29. Coipan EC, Vladimirescu AF, Ciolpan O, Teodorescu I. Tick species (Acari: Ixodoidea) distribution, seasonality and host associations in Romania. Travaux du Muséum National d'Histoire Naturelle Grigore Antipa. 2011;54:301-17.

30. Tomanović S, Chochlakis D, Radulović Ž, Milutinović M, Ćakić S, Mihaljica D, et al. Analysis of pathogen co-occurrence in host-seeking adult hard ticks from Serbia. Exp App Acarol. 2013; doi:10.1007/s10493-012-9597-y.

31. Krčmar S, Vereš M, Trliar T. Fauna of hard ticks (Acari: Ixodidae) in different habitats in Croatian part of Baranja. Šumarski List. 2014;5-6:309-14.

32. Mihaljica D, Radulović Z, Tomanović S, Cakić S, Penezić A, Milutinović M. Molecular detection of Babesia in ticks in northern Serbia. Arch Biol Sci Belgrade. 2012;64:1591-98.

33. Omeragic J. Ixodid ticks in Bosnia and Herzegovina. Exp Appl Acarol. 2011;53:301-09.

34. Garcia-Sanmartin J, Barandika JF, Juste RA, Garcia-Perez AL, Hurtado A. Distribution and molecular detection of Theileria and Babesia in questing ticks from northern Spain. Med Vet Entomol. 2008;22(4):318-25.

35. Kjær LJ, Soleng A, Edgar KS, Lindstedt HEH, Paulsen KM, Andreassen ÅK, et al. A large-scale screening for the taiga tick, Ixodes persulcatus, and the meadow tick, Dermacentor reticulatus, in southern Scandinavia, 2016. Parasit Vectors. 2019; doi:1186/s13071-019-3596-3.

36. Olivieri E, Zanzani SA, Latrofa MS, Lia RP, Dantas-Torres F, Otranto D, et al. The southernmost foci of Dermacentor reticulatus in Italy and associated Babesia canis infection in dogs. Parasit Vectors. 2016; doi:10.1186/s13071-016-1502-9.

37. Bajer A, Mierzejewska EJ, Karbowiak G, Slivinska K, Alsarraf M, Rodo A, et al. Genetic diversity of a tick, Dermacentor reticulatus, in an expansion zone in central Europe. Ann Parasitol. 2016;62 Suppl 180.

38. Google Maps https://www.google.pl/maps/place/lubelskie/@51.2661284,21.7605623,8z/data=!3m1!4b1!4m5!3m4!1s0x4723ad1204d54b2b:0x1017cadc5e4c040!8m: Accessed 15 Nov 2019.

39. Bartosik K, Wisniowski L, Buczek A. Abundance and seasonal activity of adult Dermacentor reticulatus (Acari: Amblyommidae) in eastern Poland in relation to meteorological conditions and the photoperiod. Ann Agric Environ Med. 2011;18(2):340-44.

40. Buczek A, Bartosik K, Wiśniowski $Ł$, Tomasiewicz K. Changes in population abundance of adult Dermacentor reticulatus (Acari: Amblyommidae) in longterm investigations in eastern Poland. Ann Agric Environ Med. 2013;20(2):269-72.

41. Zając Z, Bartosik K, Buczek A. Factors influencing the distribution and activity of Dermacentor reticulatus (F.) ticks in an anthropopressure-unaffected area in central-eastern Poland. Ann Agric Environ Med. 2016; doi:10.5604/12321966.1203889.

42. Estrada-Peña A, Mihalca AD, Petney TN. Ticks of Europe and North Africa: a guide to species identification. Springer; 2018.

43. https://en.tutiempo.net/climate/poland.html. Accessed 15 Nov 2019.

44. Kondracki J. Regional geography of Poland. 3rd ed. PWN; 2009. (In Polish).

45. Glazunov YV, Glazunova LA. Dermacentor reticulatus biorhythms in the Northern Forest-Steppe of the Tyumen Region. Atlantis Press. 2018; org/10.2991/agrosmart-18.2018.42.

46. Sonenshine DE. Pheromones and other semiochemicals of ticks and their use in tick control. Parasitology. 2004;129(1):405-25. 
47. Bartosik K, Wiśniowski Ł, Buczek, A. Questing behavior of Dermacentor reticulatus adults (Acari: Amblyommidae) during diurnal activity periods in eastern Poland. J Med Entomol. 2012;49(4):859-64.

48. Buczek A, Zając Z, Woźniak A, Kulina D, Bartosik K. Locomotor activity of adult Dermacentor reticulatus ticks (Ixodida: Ixodidae) in natural conditions. Ann Agric Environ Med. 2017; doi:10.5604/12321966.1230736.

49. Buczek A, Bartosik K, Zając Z. Changes in the activity of adult stages of Dermacentor reticulatus (Ixodida: Amblyommidae) induced by weather factors in eastern Poland. Parasit Vectors. 2014; doi:10.1186/1756-3305-7-245.

50. Kiewra D, Czułowska A, Lonc E. Winter activity of Dermacentor reticulatus (Fabricius, 1794) in the newly emerging population of Lower Silesia, south-west Poland. Ticks Tick Borne Dis. 2016; doi:10.1016/j.ttbdis.2016.08.012.

51. Zahler M. The ecology of Dermacentor reticulatus (Fabricius, 1794) (Parasitiformes: Ixidida: Ixodidae). München: Diss Med Vet; 1994. (In German).

52. Mierzejewska EJ, Estrada-Peña A, Bajer A. Spread of Dermacentor reticulatus is associated with the loss of forest area. Exp App Acarol. 2017; doi:10.1007/s10493-017-0160-8.

53. Martinod S, Gilot B. Epidemiology of canine babesiosis in relation to the activity of Dermacentor reticulatus in southern Jura (France). Exp App Acarol. 1991;11(2-3):215-22.

54. Bogdaszewska Z. Range and ecology of Dermacentor reticulatus (Fabricius, 1794) in Mazuria focus. II. Seasonal activity patterns of the adults. Ann parasitol. 2004;(4):731-738.

55. Cios H. Risk assessment for Ixodes ricinus tick attacks in various climatic regions of the Lublin region. PhD Thesis. Medical University of Lublin, Lublin. 2014. (In Polish).

56. Migdał W, Zając M, Rutkowska-Mazur A, Migdał Ł. Wild boar - ASF threat and meat management. Przegląd Hodowlany. 2018;4:1-5. (In Polish)

57. Ortuno A, Quesada M, Lopez-Claessens S, Castella J, Sanfeliu I, Anton E, et al. The role of wild boar (Sus scrofa) in the eco-epidemiology of slovaca in northeastern Spain. Vector Borne Zoonotic Dis. 2007;7(1):59-64.

58. Zając V, Wójcik-Fatla A, Sawczyn A, Cisak E, Sroka, J, Kloc A, et al. Prevalence of infections and co-infections with 6 pathogens in Dermacentor reticulatus ticks collected in eastern Poland. Ann Agric Environ Med. 2017; doi:10.5604/12321966.1233893.

59. Daniels TJ, Boccia TM, Varde S, Marcus J, Le J, Bucher DJ, et al. Geographic risk for Lyme disease and human granulocytic ehrlichiosis in southern New York State. Appl Environ Microbiol. 1998;64(12):4663-69.

60. Adaszek Ł, Kalinowski M, Kutrzuba J, Ziętek J, Winiarczyk S. Difficulties in diagnosing of Lyme disease in dogs. Życie Wet. 2010;85:414-17. (In Polish).

61. Adaszek $Ł$, Winiarczyk S, Puchalski A, Garbal M, Górna M. The diagnose of Borrelia afzelii infections in dogs. Ann UMCS Sect DD. 2009;64:15-21.

62. Winiarczyk S, Adaszek L, Stefancikova A, Pet'ko B, Cislakova L, Puchalski A. Serological tests for Lyme disease and erlichiosis of pigs and cows in the Lublin region. Med Vet. 2007;63(05):561-65.

63. Regional Geography of Poland. Wikipedia https://pl.wikipedia.org/wiki/Regionalizacja_fizycznogeograficzna_Polski\#/media/Plik:Regiony_Kondrackiegohipsometria.png. Accessed 1 Nov 2019.

64. Europe. Wikipedia.https://pl.wikipedia.org/wiki/Europa\#/media/Plik:Europe_topography_map.png. Accessed 1 Nov 2019.

\section{Tables}

Table 1.Structure of the landscape in the study area and D. reticulatus ticks density per $100 \mathrm{~m}^{2}$ 


\begin{tabular}{|c|c|c|c|c|c|c|c|c|c|c|c|c|c|c|c|c|c|}
\hline \multirow{4}{*}{$\begin{array}{l}\text { Square } \\
\text { number }\end{array}$} & \multirow{2}{*}{\multicolumn{4}{|c|}{ Landscape structure }} & \multicolumn{13}{|c|}{ Ticks density per $100 \mathrm{~m}^{2}$} \\
\hline & & & & & & & ing & & & & Aut & Imn & & & Total & study $\mathrm{p}$ & eriod \\
\hline & $\begin{array}{c}\text { Farmlands } \\
{[\%]}\end{array}$ & $\begin{array}{c}\text { Forests } \\
{[\%]}\end{array}$ & $\begin{array}{c}\text { Meadows } \\
{[\%]}\end{array}$ & $\begin{array}{c}\text { Other } \\
{[\%]}\end{array}$ & $\begin{array}{r}\text { We } \\
\text { paral }\end{array}$ & $\begin{array}{l}\text { her } \\
\text { eters }\end{array}$ & & ks der & sity & $\begin{array}{r}\text { We } \\
\text { parar }\end{array}$ & $\begin{array}{l}\text { her } \\
\text { eters }\end{array}$ & Tic & ks der & nsity & & $\begin{array}{l}\text { erage ti } \\
\text { density }\end{array}$ & \\
\hline & & & & & $\mathrm{T}[\stackrel{\circ}{ } \mathrm{C}]$ & $\mathrm{H}[\%]$ & $\mathrm{F}$ & $\mathrm{M}$ & $\mathrm{F}+\mathrm{M}$ & $\mathrm{T}\left[{ }^{\circ} \mathrm{C}\right]$ & $\mathrm{H}[\%]$ & $\mathrm{F}$ & $\mathrm{M}$ & $\mathrm{F}+\mathrm{M}$ & $\mathrm{F}$ & $\mathrm{M}$ & $\mathrm{F}+\mathrm{M}$ \\
\hline 1 & 67.21 & 13.5 & 5.21 & 14.08 & 12.1 & 88.8 & 84 & 54 & 138 & 22.5 & 60.0 & 98 & 61 & 159 & 91 & 57.5 & 148.5 \\
\hline 2 & 68.00 & 20.65 & 5.98 & 5.37 & 10.8 & 87.0 & 105 & 75 & 180 & 21.8 & 70.6 & 150 & 122 & 272 & 127.5 & 98.5 & 226 \\
\hline 3 & 61.00 & 15.59 & 5.23 & 18.18 & 13.4 & 90.6 & 29 & 14 & 43 & 23.2 & 70.1 & 100 & 69 & 169 & 64.5 & 41.5 & 106 \\
\hline 4 & 55.11 & 29.96 & 7.99 & 6.94 & 13.5 & 80.5 & 74 & 51 & 125 & 23.1 & 70.6 & 112 & 82 & 194 & 93 & 66.5 & 159.5 \\
\hline 5 & 79.56 & 5.66 & 2.05 & 12.73 & 14.1 & 86.0 & 153 & 93 & 246 & 19.6 & 81.0 & 177 & 106 & 283 & 165 & 99.5 & 264.5 \\
\hline 6 & 65.12 & 18.20 & 6.78 & 9.90 & 15.1 & 75.4 & 45 & 25 & 70 & 20.5 & 67.5 & 130 & 96 & 226 & 87.5 & 60.5 & 148 \\
\hline 7 & 80.12 & 10.10 & 4.11 & 5.67 & 14.8 & 81.2 & 105 & 66 & 171 & 22.5 & 66.0 & 164 & 102 & 266 & 134.5 & 84 & 218.5 \\
\hline 8 & 64.99 & 18.70 & 6.78 & 9.53 & 14.7 & 70.0 & 201 & 51 & 252 & 23.4 & 72.5 & 248 & 122 & 370 & 224.5 & 86.5 & 311 \\
\hline 9 & 40.00 & 45.03 & 6.50 & 8.47 & 17.5 & 77.0 & 96 & 48 & 144 & 21.0 & 77.8 & 190 & 134 & 324 & 143 & 91 & 234 \\
\hline 10 & 71.20 & 11.96 & 8.98 & 7.86 & 16.1 & 86.0 & 44 & 30 & 74 & 19.8 & 69.0 & 116 & 81 & 197 & 80 & 55.5 & 135.5 \\
\hline 11 & 55.10 & 30.11 & 8.21 & 6.58 & 14.5 & 70.5 & 93 & 93 & 186 & 20.0 & 54.2 & 170 & 110 & 280 & 131.5 & 101.5 & 233 \\
\hline 12 & 73.30 & 16.41 & 6.10 & 4.19 & 12.9 & 77.9 & 26 & 19 & 45 & 18.5 & 70.5 & 145 & 98 & 243 & 85.5 & 58.5 & 144 \\
\hline 13 & 85.23 & 4.29 & 2.70 & 7.78 & 15.0 & 84.2 & 31 & 36 & 67 & 17.5 & 81.2 & 56 & 36 & 92 & 43.5 & 36 & 79.5 \\
\hline 14 & 77.40 & 13.04 & 1.80 & 7.76 & 12.1 & 81.8 & 75 & 39 & 114 & 16.1 & 84.2 & 88 & 24 & 112 & 81.5 & 31.5 & 113 \\
\hline 15 & 83.90 & 3.61 & 6.67 & 5.82 & 13.7 & 74.0 & 123 & 87 & 210 & 15.1 & 75.9 & 196 & 108 & 304 & 159.5 & 97.5 & 257 \\
\hline 16 & 65.21 & 18.47 & 7.45 & 8.87 & 11.9 & 86.1 & 84 & 42 & 126 & 13.9 & 77.7 & 99 & 55 & 154 & 91.5 & 48.5 & 140 \\
\hline 17 & 60.21 & 25.00 & 7.00 & 7.79 & 15.6 & 82.0 & 102 & 81 & 183 & 18.8 & 78.3 & 190 & 100 & 290 & 146 & 90.5 & 236.5 \\
\hline 18 & 55.12 & 30.56 & 6.12 & 8.20 & 16.1 & 76.0 & 42 & 35 & 77 & 20.5 & 71.0 & 64 & 31 & 95 & 53 & 33 & 86 \\
\hline 19 & 65.12 & 24.87 & 3.15 & 6.86 & 18.5 & 67.0 & 68 & 56 & 124 & 16.9 & 79.9 & 133 & 70 & 203 & 100.5 & 63 & 163.5 \\
\hline 20 & 65.18 & 17.30 & 7.87 & 9.65 & 22.0 & 66.0 & 166 & 122 & 288 & 21.0 & 65.7 & 180 & 135 & 315 & 173 & 128.5 & 301.5 \\
\hline 21 & 80.99 & 6.68 & 2.10 & 10.23 & 19.5 & 69.9 & 177 & 69 & 246 & 23.0 & 69.0 & 75 & 50 & 125 & 126 & 59.5 & 185.5 \\
\hline 22 & 70.36 & 21.67 & 3.98 & 3.99 & 15.4 & 78.9 & 129 & 99 & 228 & 22.0 & 54.9 & 60 & 64 & 124 & 94.5 & 81.5 & 176 \\
\hline 23 & 71.33 & 18.90 & 5.00 & 4.77 & 16.7 & 69.2 & 100 & 65 & 165 & 19.8 & 55.0 & 62 & 41 & 103 & 81 & 53 & 134 \\
\hline 24 & 60.12 & 25.53 & 7.00 & 7.35 & 14.8 & 67.0 & 141 & 75 & 216 & 17.5 & 87.0 & 36 & 18 & 54 & 88.5 & 46.5 & 135 \\
\hline 25 & 45.00 & 39.56 & 7.11 & 8.33 & 10.5 & 90.5 & 15 & 13 & 28 & 16.4 & 80.0 & 20 & 50 & 70 & 17.5 & 31.5 & 49 \\
\hline 26 & 70.01 & 12.24 & 3.98 & 13.77 & 11.0 & 82.0 & 45 & 39 & 84 & 17.0 & 81.0 & 26 & 13 & 39 & 35.5 & 26 & 61.5 \\
\hline 27 & 50.98 & 32.11 & 3.00 & 13.91 & 19.3 & 82.8 & 22 & 11 & 33 & 13.6 & 88.0 & 66 & 22 & 88 & 44 & 16.5 & 60.5 \\
\hline 28 & 70.11 & 17.53 & 6.18 & 6.18 & 18.5 & 71.6 & 49 & 22 & 71 & 17.4 & 80.2 & 66 & 50 & 116 & 57.5 & 36 & 93.5 \\
\hline 29 & 70.96 & 11.72 & 5.23 & 12.09 & 17.1 & 75.9 & 75 & 35 & 110 & 23.1 & 65.0 & 59 & 66 & 125 & 67 & 50.5 & 117.5 \\
\hline 30 & 55.00 & 25.84 & 8.01 & 13.15 & 16.5 & 65.0 & 45 & 25 & 70 & 22.0 & 53.2 & 58 & 44 & 102 & 51.5 & 34.5 & 86 \\
\hline 31 & 40.19 & 43.67 & 5.00 & 11.14 & 10.7 & 83.0 & 61 & 50 & 111 & 24.8 & 55.0 & 84 & 68 & 152 & 72.5 & 59 & 131.5 \\
\hline 32 & 71.11 & 18.31 & 5.45 & 5.13 & 10.9 & 81.0 & 40 & 34 & 74 & 25.6 & 45.7 & 37 & 10 & 47 & 38.5 & 17 & 55.5 \\
\hline 33 & 35.23 & 56.19 & 4.00 & 4.58 & 13.5 & 73.5 & 25 & 18 & 43 & 24.0 & 58.0 & 62 & 35 & 97 & 43.5 & 26.5 & 70 \\
\hline 34 & 14.18 & 72.00 & 9.12 & 4.70 & 13.0 & 79.0 & 18 & 11 & 29 & 20.9 & 74.8 & 15 & 5 & 20 & 16.5 & 8 & 24.5 \\
\hline 35 & 69.27 & 19.45 & 5.00 & 6.28 & 14.0 & 65.8 & 26 & 17 & 43 & 14.5 & 80.0 & 30 & 32 & 62 & 28 & 24.5 & 52.5 \\
\hline 36 & 78.16 & 8.00 & 7.12 & 6.72 & 13.7 & 58.9 & 69 & 96 & 165 & 15.6 & 69.0 & 60 & 58 & 118 & 64.5 & 77 & 141.5 \\
\hline 37 & 80.50 & 2.03 & 5.90 & 11.57 & 11.0 & 70.0 & 58 & 60 & 118 & 20.5 & 73.3 & 34 & 26 & 60 & 46 & 43 & 89 \\
\hline 38 & 80.10 & 9.06 & 4.17 & 6.67 & 9.5 & 79.0 & 144 & 81 & 225 & 22.0 & 60.0 & 14 & 12 & 26 & 79 & 46.5 & 125.5 \\
\hline 39 & 68.00 & 16.29 & 5.22 & 4.49 & 12.5 & 78.0 & 181 & 98 & 279 & 23.0 & 62.4 & 84 & 66 & 150 & 132.5 & 82 & 214.5 \\
\hline 40 & 60.05 & 25.24 & 7.01 & 7.70 & 13.1 & 85.0 & 120 & 111 & 231 & 21.0 & 55.8 & 58 & 30 & 88 & 89 & 70.5 & 159.5 \\
\hline 41 & 65.19 & 14.06 & 8.08 & 12.67 & 13.0 & 68.9 & 194 & 137 & 331 & 22.1 & 67.0 & 57 & 36 & 93 & 125.5 & 86.5 & 212 \\
\hline 42 & 50.00 & 40.00 & 5.23 & 4.77 & 14.9 & 60.1 & 80 & 60 & 140 & 20.5 & 73.8 & 15 & 6 & 21 & 47.5 & 33 & 80.5 \\
\hline 43 & 30.12 & 60.00 & 4.00 & 5.88 & 12.0 & 68.3 & 44 & 22 & 66 & 23.5 & 73.0 & 16 & 22 & 38 & 30 & 22 & 52 \\
\hline 44 & 61.87 & 23.32 & 2.55 & 12.26 & 14.7 & 67.0 & 63 & 66 & 129 & 16.9 & 83.8 & 85 & 80 & 165 & 74 & 73 & 147 \\
\hline 45 & 80.99 & 9.26 & 2.99 & 6.76 & 13.0 & 78.0 & 35 & 18 & 53 & 18.0 & 80.6 & 4 & 12 & 16 & 19.5 & 15 & 34.5 \\
\hline 46 & 90.01 & 1.35 & 1.81 & 6.83 & 11.0 & 77.0 & 10 & 8 & 18 & 23.5 & 75.5 & 32 & 20 & 52 & 21 & 14 & 35 \\
\hline 47 & 50.09 & 6.01 & 5.00 & 38.90 & 9.1 & 85.0 & 46 & 36 & 82 & 25.7 & 49.0 & 90 & 61 & 151 & 68 & 48.5 & 116.5 \\
\hline 48 & 58.98 & 29.05 & 4.90 & 7.07 & 8.5 & 88.0 & 28 & 18 & 46 & 23.0 & 57.0 & 20 & 26 & 46 & 24 & 22 & 46 \\
\hline 49 & 70.76 & 13.03 & 6.98 & 9.23 & 12.0 & 80.0 & 82 & 60 & 142 & 21.9 & 69.8 & 80 & 71 & 151 & 81 & 65.5 & 146.5 \\
\hline 50 & 76.32 & 13.50 & 4.12 & 6.06 & 12.9 & 83.5 & 44 & 40 & 84 & 22.0 & 74.0 & 16 & 11 & 27 & 30 & 25.5 & 55.5 \\
\hline 51 & 64.95 & 18.73 & 4.76 & 11.56 & 12.6 & 81.1 & 30 & 18 & 48 & 17.0 & 87.0 & 10 & 9 & 19 & 20 & 13.5 & 33.5 \\
\hline 52 & 65.85 & 18.31 & 5.98 & 9.86 & 13.0 & 78.8 & 21 & 12 & 33 & 12.9 & 88.0 & 12 & 7 & 19 & 16.5 & 9.5 & 26 \\
\hline 53 & 75.66 & 13.53 & 1.90 & 8.91 & 10.8 & 90.0 & 26 & 9 & 35 & 15.6 & 76.0 & 74 & 77 & 151 & 50 & 43 & 93 \\
\hline 54 & 76.98 & 13.04 & 1.40 & 8.58 & 12.0 & 81.5 & 18 & 24 & 42 & 19.9 & 73.1 & 32 & 20 & 52 & 25 & 22 & 47 \\
\hline 55 & 80.01 & 6.03 & 1.00 & 12.96 & 15.9 & 75.0 & 12 & 16 & 28 & 17.8 & 72.7 & 29 & 12 & 41 & 20.5 & 14 & 34.5 \\
\hline 56 & 82.03 & 6.20 & 3.09 & 8.68 & 17.5 & 74.1 & 36 & 20 & 56 & 17.0 & 60.6 & 10 & 2 & 12 & 23 & 11 & 34 \\
\hline 57 & 79.06 & 8.30 & 5.99 & 6.65 & 14.0 & 81.0 & 56 & 48 & 104 & 13.0 & 90.0 & 14 & 9 & 23 & 35 & 28.5 & 63.5 \\
\hline 58 & 71.11 & 13.06 & 6.89 & 8.94 & 18.3 & 70.0 & 40 & 22 & 62 & 11.9 & 93.2 & 28 & 12 & 40 & 34 & 17 & 51 \\
\hline 59 & 70.20 & 15.74 & 6.34 & 7.72 & 16.4 & 65.3 & 18 & 16 & 34 & 15.7 & 85.2 & 16 & 22 & 38 & 17 & 19 & 36 \\
\hline 60 & 40.56 & 39.62 & 8.00 & 11.82 & 17.5 & 53.8 & 35 & 23 & 58 & 20.1 & 74.8 & 7 & 11 & 18 & 21 & 17 & 38 \\
\hline 61 & 74.58 & 10.24 & 6.12 & 9.06 & 15.0 & 67.0 & 78 & 75 & 153 & 20.0 & 67.0 & 25 & 29 & 54 & 51.5 & 52 & 103.5 \\
\hline 62 & 50.75 & 35.65 & 4.00 & 9.60 & 14.8 & 74.9 & 22 & 10 & 32 & 23.1 & 63.0 & 25 & 17 & 42 & 23.5 & 13.5 & 37 \\
\hline 63 & 80.00 & 8.16 & 2.98 & 8.86 & 10.5 & 80.3 & 45 & 12 & 57 & 19.5 & 76.9 & 84 & 76 & 160 & 64.5 & 44 & 108.5 \\
\hline 64 & 71.00 & 18.01 & 3.09 & 7.90 & 11.0 & 86.0 & 36 & 45 & 81 & 19.0 & 71.0 & 12 & 8 & 20 & 24 & 26.5 & 50.5 \\
\hline 65 & 65.07 & 15.63 & 5.01 & 14.29 & 9.1 & 80.0 & 15 & 10 & 25 & 23.3 & 46.0 & 11 & 6 & 17 & 13 & 8 & 21 \\
\hline 66 & 89.88 & 1.85 & 1.03 & 7.24 & 17.4 & 70.0 & 14 & 7 & 21 & 18.7 & 69.4 & 12 & 11 & 23 & 13 & 9 & 22 \\
\hline 67 & 80.09 & 6.71 & 2.00 & 11.20 & 21.4 & 58.8 & 4 & 1 & 5 & 16.6 & 78.0 & 2 & 4 & 6 & 3 & 2.5 & 5.5 \\
\hline 68 & 87.33 & 3.32 & 1.33 & 8.02 & 22.0 & 54.7 & 26 & 8 & 34 & 20.4 & 71.0 & 26 & 24 & 50 & 26 & 16 & 42 \\
\hline 69 & 70.45 & 17.77 & 2.03 & 9.75 & 17.0 & 55.0 & 297 & 219 & 516 & 21.1 & 72.8 & 68 & 34 & 102 & 182.5 & 126.5 & 309 \\
\hline 70 & 69.79 & 15.01 & 5.12 & 10.08 & 16.0 & 70.7 & 33 & 7 & 40 & 22.2 & 77.1 & 30 & 31 & 61 & 31.5 & 19 & 50.5 \\
\hline 71 & 70.56 & 18.76 & 2.34 & 8.34 & 16.5 & 70.0 & 18 & 15 & 33 & 20.6 & 68.5 & 29 & 31 & 60 & 23.5 & 23 & 46.5 \\
\hline
\end{tabular}




\begin{tabular}{|c|c|c|c|c|c|c|c|c|c|c|c|c|c|c|c|c|c|}
\hline 72 & 44.87 & 42.16 & 6.00 & 6.97 & 15.3 & 78.3 & 60 & 54 & 114 & 25.0 & 62.2 & 45 & 22 & 67 & 52.5 & 38 & 90.5 \\
\hline 73 & 10.00 & 85.00 & 1.93 & 3.07 & 19.5 & 75.0 & 16 & 8 & 24 & 19.0 & 70.5 & 26 & 20 & 46 & 21 & 14 & 35 \\
\hline 74 & 29.09 & 61.00 & 4.09 & 5.82 & 18.0 & 65.8 & 15 & 14 & 29 & 18.7 & 76.0 & 18 & 12 & 30 & 16.5 & 13 & 29.5 \\
\hline 75 & 75.00 & 7.45 & 1.31 & 16.24 & 18.0 & 51.2 & 12 & 11 & 23 & 16.5 & 79.1 & 19 & 6 & 25 & 15.5 & 8.5 & 24 \\
\hline 76 & 80.34 & 10.86 & 3.05 & 5.75 & 16.5 & 55.5 & 42 & 16 & 58 & 20.2 & 78.5 & 36 & 10 & 46 & 39 & 13 & 52 \\
\hline 77 & 70.91 & 15.23 & 5.09 & 8.77 & 14.7 & 69.0 & 52 & 37 & 89 & 20.5 & 68.0 & 23 & 2 & 25 & 37.5 & 19.5 & 57 \\
\hline 78 & 75.03 & 7.80 & 6.99 & 10.18 & 17.7 & 64.7 & 7 & 6 & 13 & 22.8 & 70.0 & 41 & 31 & 72 & 24 & 18.5 & 42.5 \\
\hline 79 & 79.00 & 7.54 & 6.28 & 7.18 & 18.5 & 70.5 & 17 & 6 & 23 & 25.6 & 71.4 & 28 & 25 & 53 & 22.5 & 15.5 & 38 \\
\hline 80 & 83.00 & 5.67 & 4.00 & 7.33 & 20.8 & 70.0 & 66 & 60 & 126 & 24.0 & 72.8 & 88 & 46 & 134 & 77 & 53 & 130 \\
\hline 81 & 5.21 & 82.12 & 2.00 & 10.67 & 21.0 & 61.0 & 21 & 9 & 30 & 20.0 & 70.0 & 18 & 12 & 30 & 19.5 & 10.5 & 30 \\
\hline 82 & 20.09 & 70.10 & 3.65 & 6.16 & 22.0 & 73.2 & 33 & 12 & 45 & 21.9 & 65.2 & 24 & 10 & 34 & 28.5 & 11 & 39.5 \\
\hline 83 & 45.67 & 40.87 & 4.01 & 9.45 & 19.0 & 65.0 & 9 & 13 & 22 & 25.5 & 73.6 & 26 & 24 & 50 & 17.5 & 18.5 & 36 \\
\hline 84 & 38.87 & 53.00 & 3.01 & 5.12 & 22.3 & 76.8 & 54 & 40 & 94 & 23.0 & 77.0 & 30 & 23 & 53 & 42 & 31.5 & 73.5 \\
\hline 85 & 59.91 & 18.97 & 7.98 & 13.14 & 16.5 & 80.0 & 41 & 14 & 55 & 19.0 & 78.9 & 52 & 78 & 130 & 46.5 & 46 & 92.5 \\
\hline 86 & 75.67 & 10.00 & 6.22 & 8.11 & 17.9 & 62.3 & 11 & 7 & 18 & 23.0 & 72.3 & 61 & 50 & 111 & 36 & 28.5 & 64.5 \\
\hline 87 & 67.99 & 7.00 & 8.88 & 16.13 & 15.4 & 62.2 & 19 & 6 & 25 & 21.2 & 70.4 & 54 & 55 & 109 & 36.5 & 30.5 & 67 \\
\hline 88 & 69.11 & 6.18 & 18.90 & 5.81 & 14.1 & 77.8 & 34 & 15 & 49 & 19.0 & 80.5 & 41 & 19 & 60 & 37.5 & 17 & 54.5 \\
\hline 89 & 15.43 & 2.33 & 58.95 & 23.29 & 19.6 & 59.0 & 29 & 14 & 43 & 24.0 & 70.0 & 44 & 30 & 74 & 36.5 & 22 & 58.5 \\
\hline 90 & 21.09 & 61.01 & 5.00 & 12.90 & 21.0 & 70.0 & 48 & 54 & 102 & 23.0 & 67.0 & 10 & 1 & 11 & 29 & 27.5 & 56.5 \\
\hline 91 & 40.99 & 48.15 & 4.87 & 5.99 & 19.0 & 66.6 & 61 & 55 & 116 & 21.0 & 79.0 & 12 & 30 & 42 & 36.5 & 42.5 & 79 \\
\hline 92 & 49.23 & 37.11 & 3.69 & 9.97 & 17.5 & 70.2 & 38 & 30 & 68 & 17.8 & 74.2 & 58 & 47 & 105 & 48 & 38.5 & 86.5 \\
\hline 93 & 67.12 & 15.27 & 7.21 & 10.40 & 16.0 & 79.5 & 20 & 10 & 30 & - & - & - & - & 0 & 20 & 10 & 15 \\
\hline 94 & 65.00 & 6.88 & 10.00 & 18.12 & 14.2 & 77.8 & 32 & 24 & 56 & 19.5 & 77.0 & 29 & 27 & 56 & 30.5 & 25.5 & 56 \\
\hline 95 & 18.99 & 1.19 & 38.00 & 41.82 & 13.3 & 77.1 & 46 & 33 & 79 & 23.1 & 70.9 & 58 & 40 & 98 & 52 & 36.5 & 88.5 \\
\hline 96 & 8.09 & 1.27 & 70.07 & 20.57 & 15.1 & 80.5 & 18 & 20 & 38 & 22.0 & 65.3 & 36 & 22 & 58 & 27 & 21 & 48 \\
\hline 97 & 65.00 & 18.45 & 4.00 & 12.55 & 16.0 & 80.1 & 9 & 7 & 16 & 19.6 & 62.1 & 20 & 14 & 34 & 14.5 & 10.5 & 25 \\
\hline 98 & 78.99 & 11.35 & 2.54 & 7.12 & 13.0 & 73.0 & 14 & 10 & 24 & 22.0 & 70.0 & 16 & 19 & 35 & 15 & 14.5 & 29.5 \\
\hline 99 & 18.98 & 70.00 & 3.10 & 7.92 & 11.9 & 79.5 & 14 & 20 & 34 & 18.8 & 69.3 & 28 & 6 & 34 & 21 & 13 & 34 \\
\hline 100 & 45.05 & 37.09 & 8.14 & 9.72 & 17.0 & 77.7 & 40 & 29 & 69 & 22.8 & 66.8 & 88 & 63 & 151 & 64 & 46 & 110 \\
\hline 101 & 57.21 & 30.12 & 6.00 & 6.67 & 16.7 & 73.6 & 34 & 16 & 50 & 23.9 & 75.5 & 82 & 50 & 132 & 58 & 33 & 91 \\
\hline
\end{tabular}

F - females, M- males, $\mathrm{T}$ - temperature, $\mathrm{H}$ - humidity

Table 2. Descriptive statistics of $D$. reticulatus ticks density per $100 \mathrm{~m}^{2}$

\begin{tabular}{cccccccc}
\hline Study period & Sex & n & Average density & SD. & Median & Min. & Max. \\
\hline Spring & F & 101 & 56.5 & 50.6 & 41.0 & 4.0 & 297.0 \\
& M & 101 & 38.4 & 34.8 & 25.0 & 1.0 & 219.0 \\
& F+M & 101 & 94.9 & 83.4 & 68.0 & 5.0 & 516.0 \\
Autumn & F & 100 & 58.9 & 51.3 & 41.0 & 2.0 & 248.0 \\
& M & 100 & 40.9 & 33.5 & 30.0 & 1.0 & 135.0 \\
Whole study period & F+M & 101 & 98.9 & 83.3 & 67.0 & 0.0 & 370.0 \\
& F & 101 & 57.5 & 44.4 & 43.5 & 3.0 & 224.5 \\
& M & 101 & 39.5 & 28.3 & 31.5 & 2.5 & 128.5 \\
& F+M & 101 & 96.8 & 71.7 & 73.5 & 5.5 & 311.0 \\
\hline
\end{tabular}

SD - standard deviation, $\mathrm{n}$ - number of plots, F - females M- males, Min- minimum, Max - Maximum

Table 3. Average collections of D. reticulatus ticks in the Polesie National Park (square 41)

\begin{tabular}{ccccccccccccc}
\hline Year & & \multicolumn{1}{c}{ Spring } & \multicolumn{1}{c}{ Autumn } \\
& $\mathrm{n}$ & $\mathrm{T}\left[{ }^{\circ} \mathrm{C}\right]$ & $\mathrm{H}[\%]$ & $\mathrm{F}$ & $\mathrm{M}$ & $\mathrm{F}+\mathrm{M}$ & $\mathrm{n}$ & $\mathrm{T}\left[{ }^{\circ} \mathrm{C}\right]$ & $\mathrm{H}[\%]$ & $\mathrm{F}$ & $\mathrm{M}$ & $\mathrm{F}+\mathrm{M}$ \\
\hline 2014 & 6 & 11.8 & 77.2 & 62 & 41 & 103 & 3 & 23.0 & 72.2 & 80 & 68 & 148 \\
2015 & 7 & 14.9 & 69.3 & 78 & 49 & 127 & 4 & 20.8 & 76.3 & 84 & 77 & 161 \\
2016 & 6 & 12.8 & 81.0 & 61 & 50 & 111 & 4 & 18.1 & 68.2 & 108 & 70 & 178 \\
2017 & 6 & 13.4 & 77.2 & 83 & 79 & 162 & 5 & 17.8 & 75.4 & 128 & 97 & 225 \\
2018 & 3 & 12.7 & 79.0 & 124 & 111 & 235 & 2 & 21.0 & 68.0 & 155 & 120 & 275 \\
2019 & 2 & 13.5 & 80.2 & 194 & 137 & 331 & 2 & 19.8 & 74.6 & 57 & 36 & 93 \\
\hline
\end{tabular}

n- number of tick collection, T - temperature, H- humidity, F - females, M- males

\section{Figures}




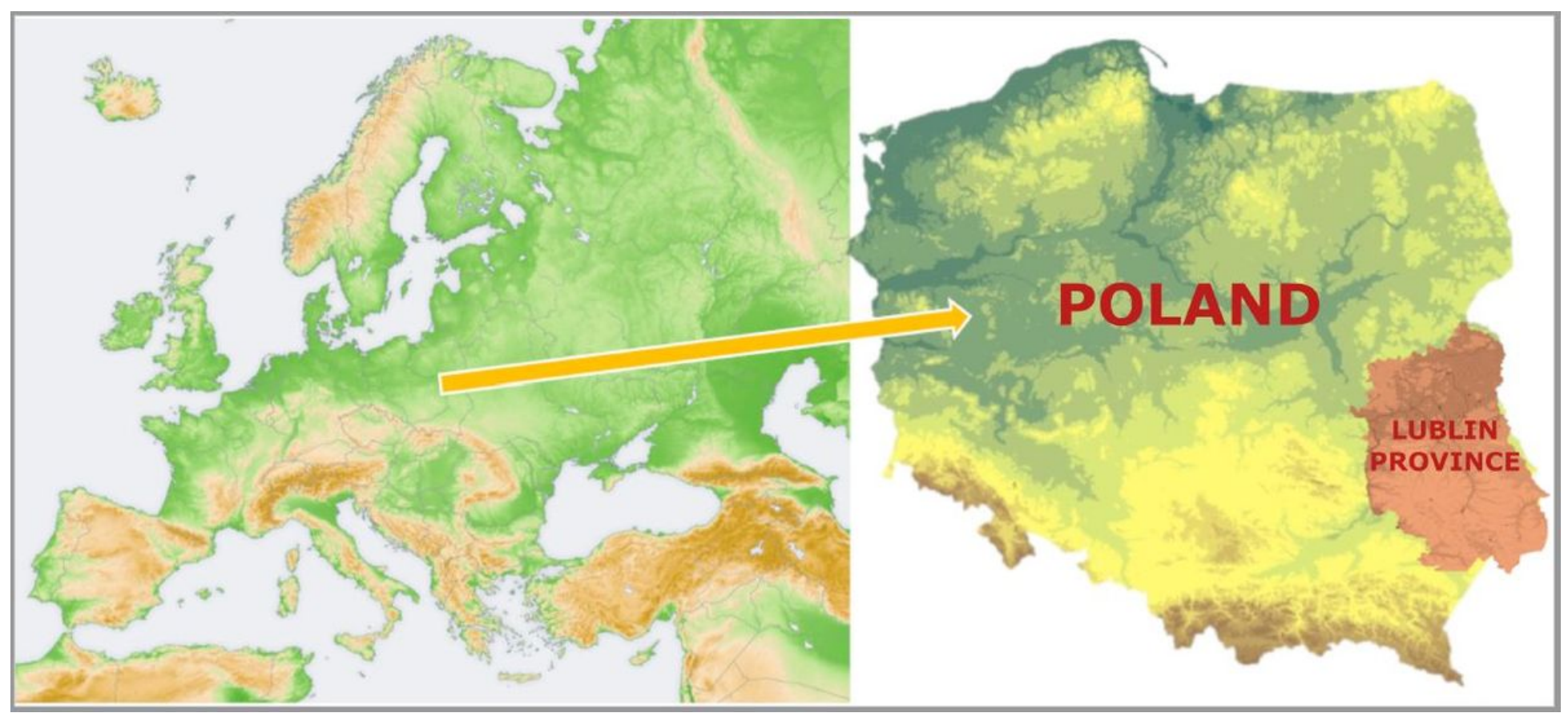

Figure 1

Localization of the study area, based on Wikipedia $[63,64]$, changed

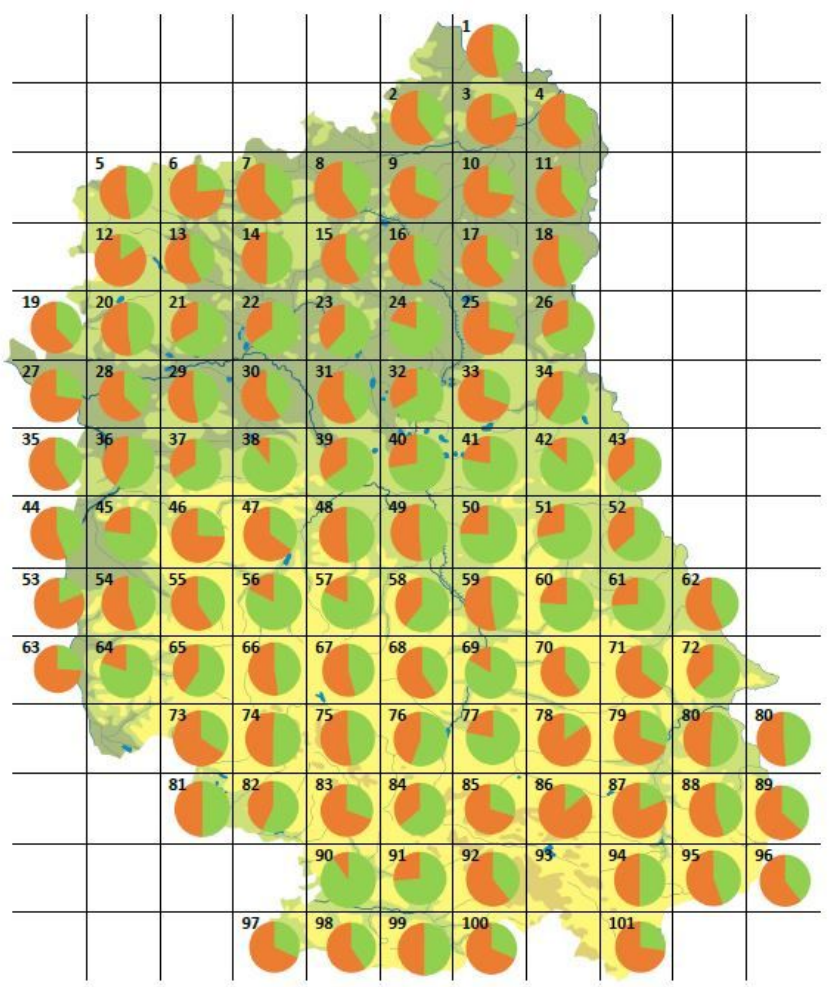

Autumn $\bigcirc$ Spring

$\underline{15 \mathrm{~km}}$

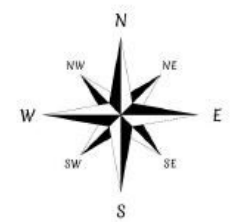

Figure 2 
Visualization of grid squares and spatial distribution of seasonal activity peaks of D. reticulatus in Lublin Province. Data are presented as absolute values, see table 1.

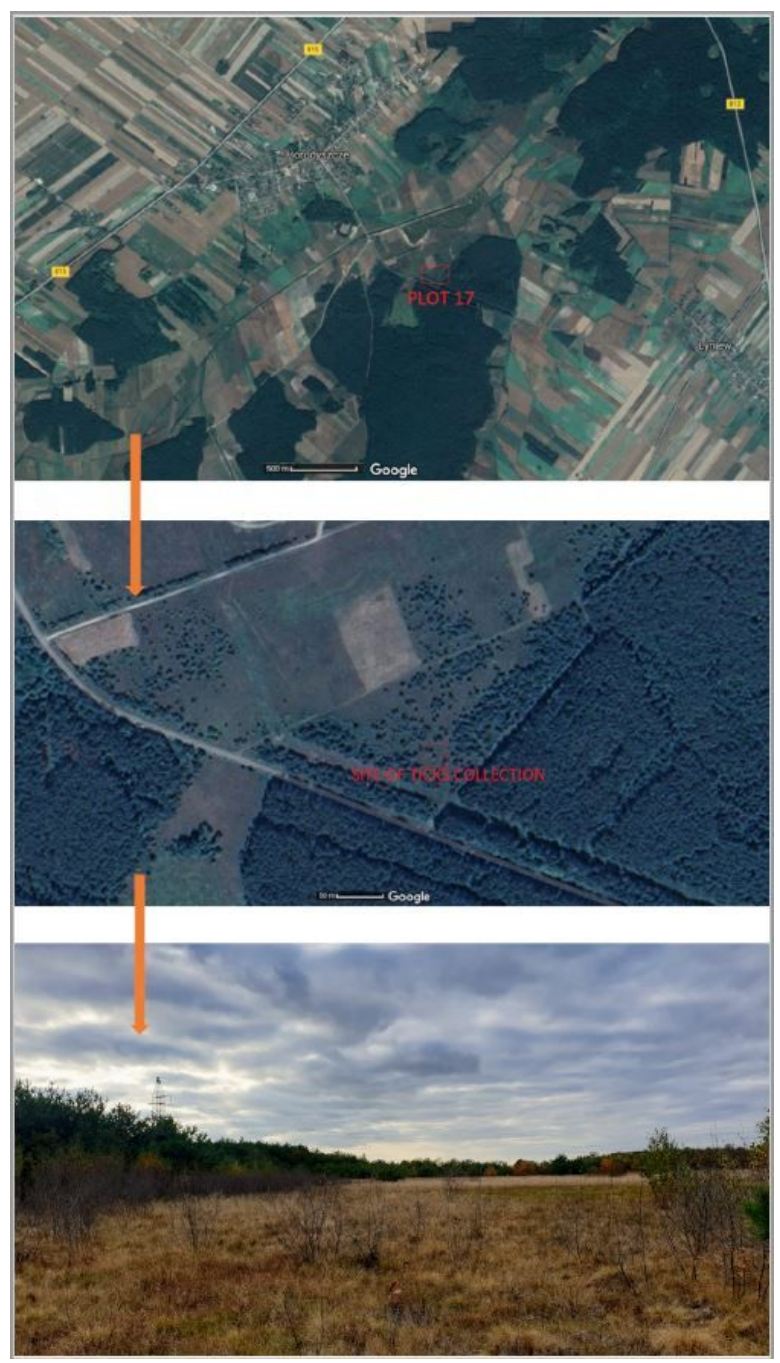

\section{Figure 3}

Method of selection of D. reticulatus collection sites, plot 17, based on Google Maps [38], changed 


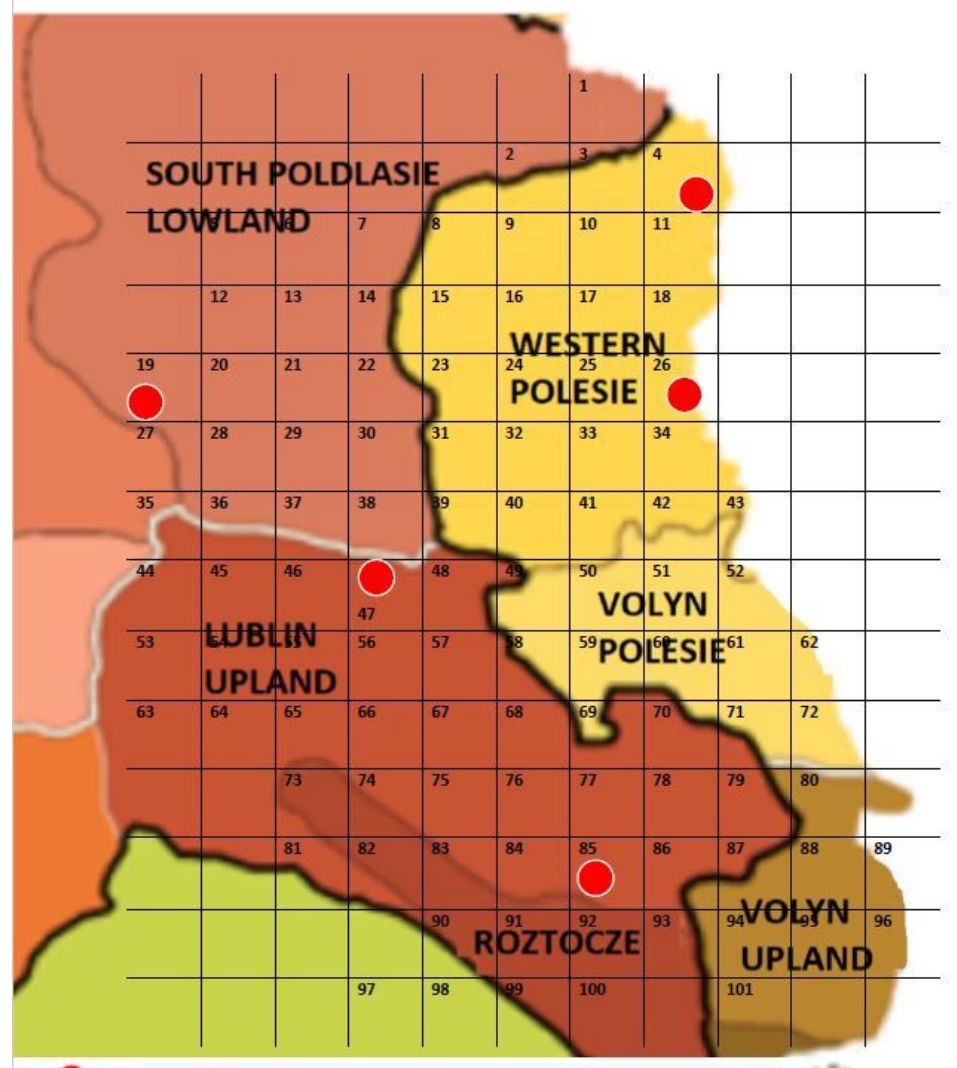

weather station (In squares: 4-Terespol, 19-Kozienice, 26-Włodawa, 47-Lublin, 85-Zamość

\section{- region border}

$\overline{15 \mathrm{~km}}$

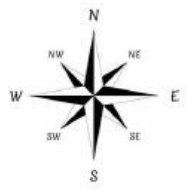

\section{Figure 4}

Physico-geographical regions of Lublin Province, location of the weather stations, based on Kondracki [44], changed 


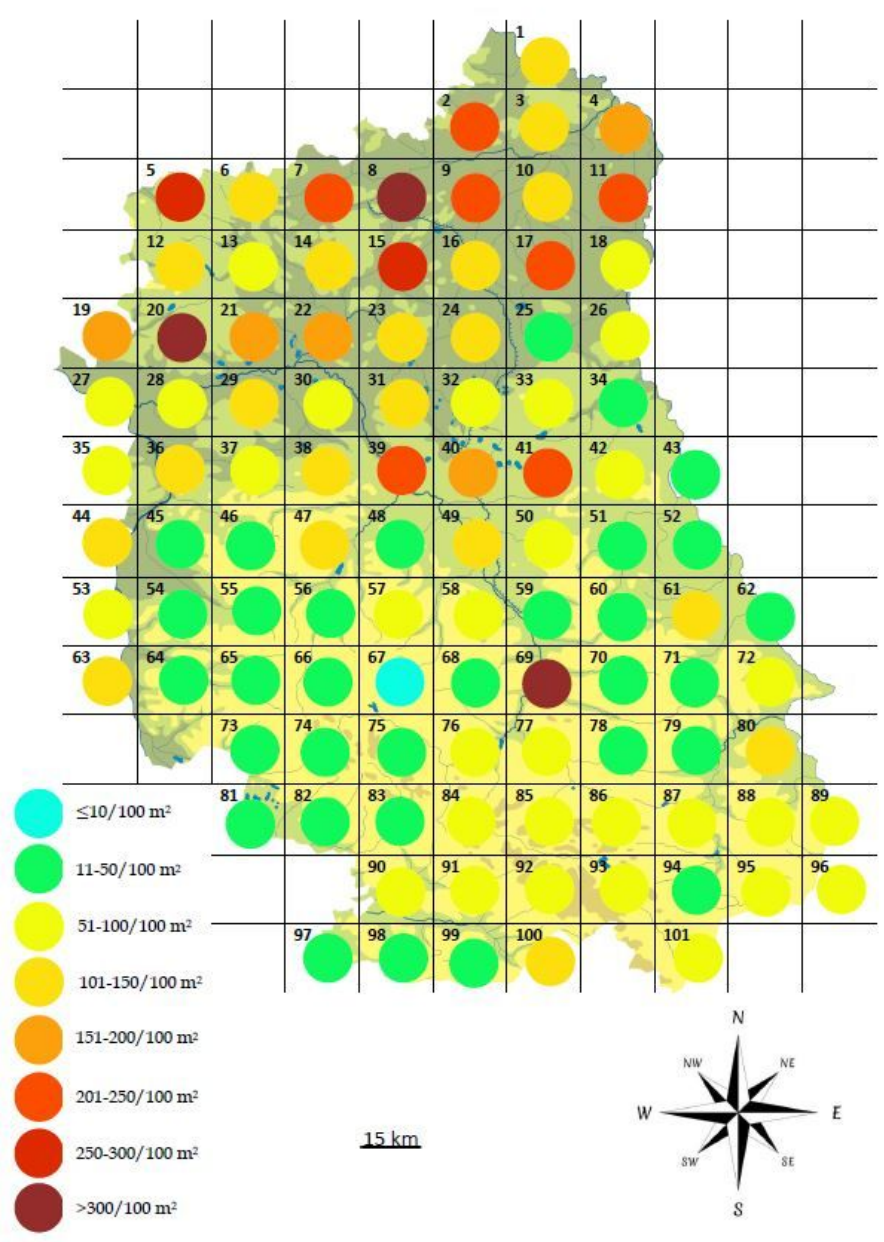

Figure 5

Spatial distribution of the average density of D. reticulatus populations in Lublin Province 


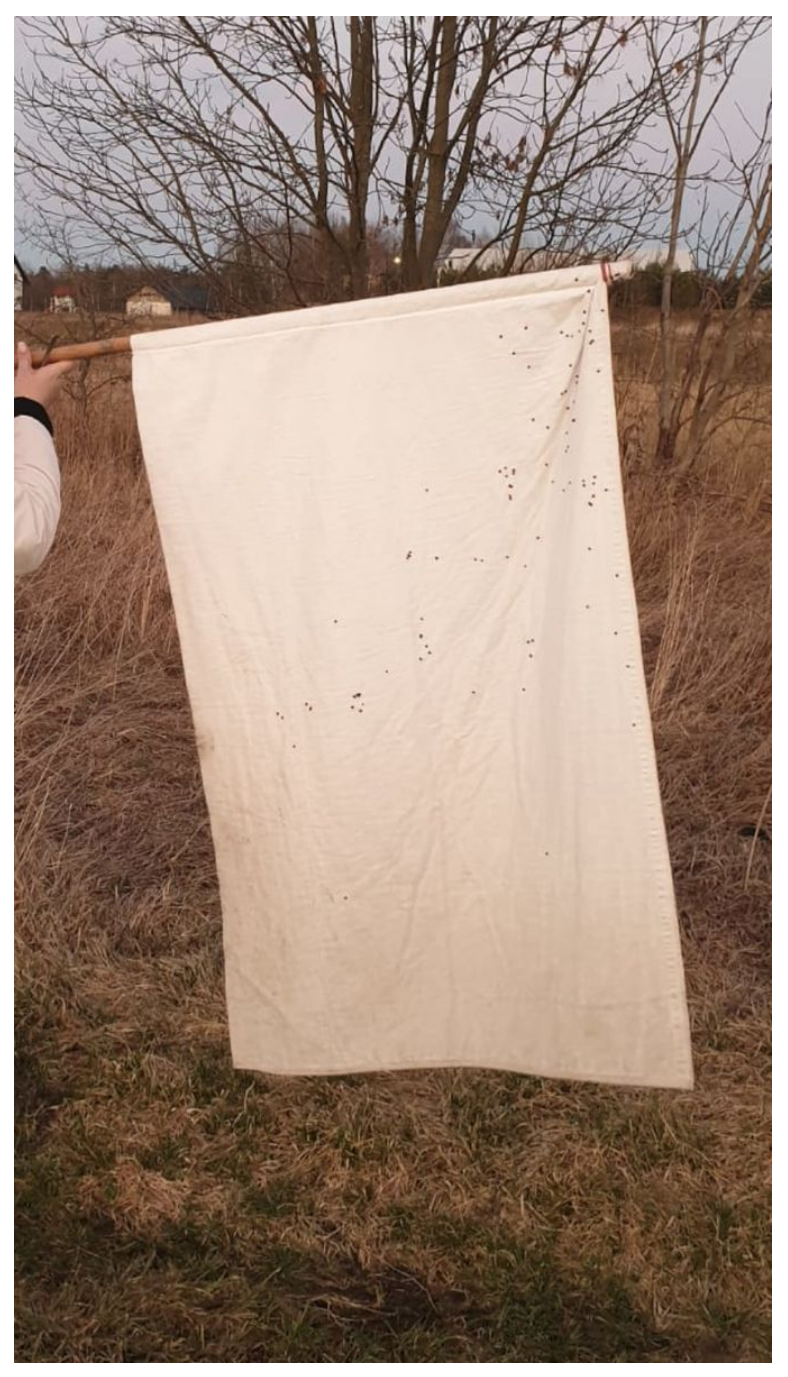

\section{Figure 6}

D. reticulatus ticks collected on an experimental field located in square 41.96 adult specimens were harvested in an area of $10 \mathrm{~m} 2$ 